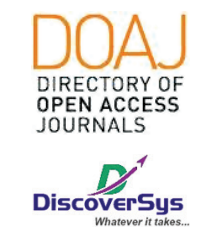

Published by DiscoverSys

\section{Gambaran aspek lingkungan dan perilaku pencegahan penularan tuberkulosis paru pada pasien tuberkulosis paru di wilayah kerja Puskesmas Dawan I, Kabupaten Klungkung tahun 2017}

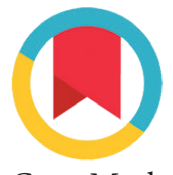

CrossMark

\author{
Yoseph Louis Helmi Rumkabu, ${ }^{1 *}$ Fatqur Rochman, ${ }^{1}$ \\ Dewa Ayu Tintyani Rahmani Wikananda, ${ }^{1}$ Putu Cintya Denny Yuliatni ${ }^{2}$
}

ABSTRAK

Pendahuluan: Tuberkulosis paru adalah penyakit reemerging dan masih ditemukan di Provinsi Bali. Untuk mengurangi bertambahnya TB paru dan masalah yang ditimbulkan, perlu dilakukan penanganan awal yang dapat dilakukan yaitu di lingkungan keluarga. Selain untuk menyembuhkan pasien dan mencegah kematian, tujuan pengobatan TB lainnya yaitu mencegah kekambuhan dan memutuskan rantai penularan.

Tujuan: Mengetahui gambaran aspek lingkungan dan perilaku pencegahan penularan tuberkulosis paru pada pasien TB Paru di wilayah kerja Puskesmas Dawan I

Metode: Penelitan ini menggunakan pendekatan deskriptif menggunakan rancangan cross-sectional pada populasi pasien TB paru di Puskesmas Dawan I, Klungkung. Sampel ditentukan melalui total sampling, yaitu pasien tuberkulosis dengan BTA (+) selama tahun
2016-2017. Instrumen yang digunakan berupa kuesioner tentang gambaran aspek lingkungan dan perilaku pencegahan penularan tuberkulosis paru. Data yang telah terkumpul dianalisa secara deskriptif dengan program SPSS.

Hasil: Gambaran responden yaitu 68,4\% usia produktif; tamatan SMA 42,1\%; PNS/pensiunan dan buruh 31,6\%; keluarga kurang mampu 47,4\%. Pada aspek lingkungan penderita TB, pencahayaan cukup 68,4\%; kamar mandi cukup 89,5\%; penghuni 1-3 orang 63,2\%; luas ventilasi kamar tidur kurang $57,9 \%$. Pada aspek pengetahuan mayoritas pengetahuan masyarakat tentang TB sudah baik.

Simpulan: Sebagian besar penderita TB paru berada pada rentang usia produktif, jenis kelamin perempuan, berpenghasilan rendah, tingkat pendidikan rata-rata SMA. Mayoritas responden memiliki tempat tinggal dan pencegahan penularan penyakit yang sudah baik.

Kata kunci: tuberkulosis paru, aspek lingkungan, pencegahan tuberkulosis

Cite Pasal Ini: Rumkabu, Y.L.H., Rochman, F., Wikananda, D.A.T.R., Yuliatni, P.C.D. 2019. Gambaran aspek lingkungan dan perilaku pencegahan penularan tuberkulosis paru pada pasien tuberkulosis paru di wilayah kerja Puskesmas Dawan I, Kabupaten Klungkung tahun 2017. Intisari Sains Medis 10(3): 543-547. D0I: 10.15562/ism.v10i3.448

'Program Studi Pendidikan Dokter, Fakultas Kedokteran Universitas Udayana

${ }^{2}$ Departemen Kedokteran Masyarakat dan Kedokteran Pencegahan, Fakultas Kedokteran Universitas Udayana

\section{"Korespondensi: \\ Yoseph Louis Helmi Rumkabu, Program Studi Pendidikan Dokter, Fakultas Kedokteran Universitas Udayana \\ helmirumkabu@gmail.com}

Diterima: 17-03-2019

Disetujui: 01-04-2019

Diterbitkan: 01-12-2019

\section{PENDAHULUAN}

Tuberkulosis adalah salah satu penyakit menular pada saluran napas, disebabkan oleh bakteri Mycobacterium tuberculosis. ${ }^{1}$ Pada negara-negara berkembang, tuberkulosis (TB) menjadi permasalahan di bidang kesehatan dengan beban yang semakin meningkat, terutama peningkatan kasus koinfeksi TB-HIV (human immunodeficiency virus). ${ }^{1,2}$

Peningkatan kasus TB disebabkan oleh resistensi obat anti tuberkulosis, angka kemiskinan yang meningkat, kepadatan penduduk bahkan tempat tinggal yang tidak sesuai standar. Pada tahun 2013, sekitar 9 juta orang terinfeksi TB dengan kasus meninggal akibat TB sekitar 1,5 juta orang menurut data WHO. ${ }^{2}$ Angka kasus TB di Indonesia cukup tinggi dengan perkiraan prevalensi sebesar 272 per 100.000 penduduk pada tahun 2014, insiden sebesar 183 per 100.000 penduduk, dan angka kematian 25 per 100.000 penduduk akibat TB. ${ }^{3}$ Laporan Global Tuberculosis Report tahun 2014 menggambarkan 5,4 juta kasus baru dan 0,3 juta kasus TB relaps. Angka kejadian TB relas terjadi di beberapa negara, India menjadi negara terbesar kasus relaps sebesar 33\%, diikuti 9\% dari Cina, 5,3\% dari Afrika Selatan, 5\% dari Rusia, dan 2,6\% dari Indonesia (pada 0,3 juta kasus TB relaps di seluruh dunia). ${ }^{4}$ Memutus rantai transmisi dan mencegah kekambuhan menjadi tujuan utama pada penanganan TB selain tujuan kuratif., ${ }^{5,6}$ Angka insiden kasus tuberkulosis di Kabupaten Klungkung periode 2011-2014 cenderung mengalami peningkatan. Semua penderita TB paru positif sebanyak 114 penderita sudah mendapat paket pengobatan TB dengan strategi DOTS (Directly Observed Treatment Short), dengan angka kesembuhan penderita TB paru (BTA+) sudah mencapai 95,95\% meningkat dibandingkan dengan tahun 2013 sebesar 86,65\% sehingga sudah mencapai target $80 \% .{ }^{7,8}$

Pencegahan penyakit dan pemutusan rantai transmisi perlu dilakukan pada tingkat keluarga. Anggota keluarga merupakan subjek yang mudah ditularkan karena tinggal dengan penderita TB 
dan cara penularan yang mudah terutama pada kondisi lingkungan padat dan tempat tinggal yang tidak sesuai terutama pada keluarga dengan ekonomi rendah dan pendidikan rendah., ${ }^{910}$ Untuk itu, mengetahui karakteristik lingkungan dan pola perilaku pencegahan transmisi tuberkulosis paru pada pasien TB Paru di wilayah kerja Puskesmas Dawan I merupakan tujuan pada penelitian ini.

\section{METODE PENELITIAN}

Penelitian ini merupakan deskriptif cross-sectional pada populasi pasien TB paru di Puskesmas Dawan I, Klungkung pada bulan November 2017. Sampel ditentukan dengan metode total sampling yaitu seluruh pasien tuberkulosis yang terdiagnosa BTA (+) pada tahun 2016-2017 yang berobat jalan di Puskesmas Dawan I. Data diperoleh melalui wawancara menggunakan kuesioner terstruktur tentang karakteristik lingkungan dan perilaku pencegahan penularan TB yang diadopsi dari penelitian sebelumnya. Data terkumpul dianalisa secara deskriptif dan ditampilkan dalam bentuk tabel dan deskripsi naratif dengan program SPSS.

\section{HASIL}

Hasil pencarian sampel secara door to door yang dilakukan peneliti, didapatkan sampel yang memenuhi kriteria sebanyak 19 sampel yang semuanya merupakan pasien terdiagnosis TB di Puskesmas Dawan 1 pada tahun 2016-2017. Data demografi meliputi jenis kelamin, usia, tingkat pendidikan, pekerjaan dan penghasilan didapatkan dari 19 responden. Karakteristik sosiodemografi secara lengkap dapat dilihat pada Tabel 1.

Sebagian besar rumah responden memiliki media sanitasi cahaya matahari yang dapat berupa jendela, lubang ventilasi udara maupun genteng kaca. Dari data kondisi fisik lingkungan didapatkan hasil mayoritas dinding rumah pasien merupakan bata/batako yang sudah plesteran $(68,4 \%)$. Lantai yang ada di rumah rumah pasien mayoritas sudah berbahan keramik (42\%). Pencahayaan pada rumah, kamar tidur dan dapur juga mayoritas didapatkan cukup (68,4\%) Mayoritas keluarga juga sudah memiliki kamar mandi keluarga sendiri (89,5\%), hanya 2 keluarga (10,5\%) yang masih menggunakan kamar mandi bersama sama keluarga besar. Mayoritas pada keluarga pasien tidak memiliki kamar khusus bila terdapat orang yang sakit (52,6\%). Mayoritas pasien TB sendiri tinggal pada hunian dengan jumlah penghuni $\leq 3$ orang $(63,2 \%)$. Dari persentase kecukupan sanitasi cahaya pada kamar tidur sendiri didapatkan hasil mayoritas masih kurang (57.9\%) (Tabel 2). Gambaran pengetahuan pasien TB dari setiap aspek pengetahuan tentang pencegahan penularan TB dapat dilihat lebih detail pada Tabel 3 .

Tabel 1 Gambaran sosiodemografi subjek penelitian

\begin{tabular}{llcc}
\hline Karakteristik & Kategori & n & Persentase \\
\hline Usia & Produktif (15-55) & 13 & 68,4 \\
Jenis Kelamin & Non produktif (<15 atau $>55)$ & 6 & 31,6 \\
Tingkat Pendidikan & Laki-laki & 9 & 47,4 \\
& Perempuan & 10 & 52,6 \\
& Tidak sekolah & 41,1 \\
& Tamat SD & 4 & 31,6 \\
& Tamat SMP & 6 & 0 \\
Tekerjaan & Tamat SMA & 0 & 42,1 \\
& Tamat D3/PT & 8 & 5,3 \\
& PNS/pensiunan & 1 & 31,6 \\
& Polri/TNI/pensiunan & 6 & 5,3 \\
& Pegawai swasta/wiraswasta & 1 & 21,1 \\
& Pedagang & 4 & 15,8 \\
& Petani & 3 & 26,3 \\
& Buruh & 5 & 31,6 \\
& Lain-lain & 6 & 5,3 \\
& Kurang mampu & 1 & 47,4 \\
& Menengah & 9 & 31,6 \\
& Mampu & 6 & 21,1 \\
\hline
\end{tabular}


Tabel 2 Gambaran aspek lingkungan penderita TB

\begin{tabular}{|c|c|c|c|}
\hline Karakteristik & Kategori & $\mathbf{n}$ & Persentase \\
\hline \multirow[t]{2}{*}{ Jenis dinding rumah } & Bata tanpa plester & 6 & 31,6 \\
\hline & Bata dengan plester & 13 & 68,4 \\
\hline \multirow[t]{4}{*}{ Jenis lantai } & Tanah & 1 & 5,3 \\
\hline & Plesteran berdebu & 6 & 31,6 \\
\hline & Plesteran halus & 4 & 21,1 \\
\hline & Keramik & 8 & 42,1 \\
\hline \multirow[t]{2}{*}{ Pencahayaan ruang keluarga } & Cukup & 14 & 73,7 \\
\hline & Kurang & 5 & 26,3 \\
\hline \multirow[t]{2}{*}{ Pencahayaan kamar tidur } & Cukup & 12 & 63,2 \\
\hline & Kurang & 7 & 36,8 \\
\hline \multirow[t]{2}{*}{ Pencahayaan pada rumah } & Cukup & 13 & 68,4 \\
\hline & Kurang & 6 & 31,6 \\
\hline \multirow[t]{2}{*}{ Kamar tersendiri } & Ada & 9 & 47,4 \\
\hline & Tidak & 10 & 52,6 \\
\hline \multirow[t]{2}{*}{ Kamar mandi } & Cukup & 17 & 89,5 \\
\hline & Kurang & 2 & 10,5 \\
\hline \multirow[t]{2}{*}{ Jumlah penghuni rumah } & $1-3$ & 12 & 63,2 \\
\hline & $>3$ & 7 & 36,8 \\
\hline \multirow[t]{3}{*}{ Jumlah penghuni kamar tidur } & 1 & 9 & 47,4 \\
\hline & 2 & 6 & 31,6 \\
\hline & 3 & 4 & 21,1 \\
\hline \multirow[t]{2}{*}{ Luas ventilasi kamar Tidur } & Cukup (>10\%) & 8 & 42,1 \\
\hline & Kurang $(<10 \%)$ & 11 & 57,9 \\
\hline \multirow[t]{2}{*}{ Luas ventilasi dapur } & Cukup $(>10 \%)$ & 10 & 52,6 \\
\hline & Kurang $(<10 \%)$ & 9 & 47,4 \\
\hline
\end{tabular}

Tabel 3 Gambaran perilaku pencegahan penularan TB

\begin{tabular}{llcc}
\hline Karakteristik & Kategori & $\mathbf{n}$ & Presentase \\
\hline Berobat teratur & $\begin{array}{l}\text { Instansi kesehatan } \\
\text { (puskesmas/klinik/RS) }\end{array}$ & 18 & $94,7 \%$ \\
& Balian/alternatif & 1 & $5,3 \%$ \\
Kepatuhan minum obat & Makan obat teratur & 19 & $100 \%$ \\
Perilaku menutup mulut & Iya & 19 & $100 \%$ \\
Perilaku meludah & Tidak & 0 & $0 \%$ \\
& Luar rumah & 4 & $21,1 \%$ \\
Perilaku membuka jendela & Toilet & 11 & $57,9 \%$ \\
& Wadah khusus & 4 & $21,1 \%$ \\
& Membuka jendela kamar tidur tiap hari & 16 & $84,2 \%$ \\
& Kadang kadang membuka jendela & 1 & $5,3 \%$ \\
Upayah pembuatan ventilasi & kamar tidur & 2 & $10,5 \%$ \\
& Tidak pernah membuka jendela & 13 & $68,4 \%$ \\
& Ventilasi memenuhi syarat & 5 & $26,3 \%$
\end{tabular}


Tabel 3 Continue

\begin{tabular}{llcc}
\hline Karakteristik & Kategori & $\mathbf{n}$ & Presentase \\
\hline Upayah pembuatan lantai ideal & Lantai keramik/plesteran halus & 13 & $68,4 \%$ \\
& Plesteran berdebu & 6 & $31,6 \%$ \\
Upaya pencahayaan sinar & Membuat dan membuka jendela & 16 & $84,2 \%$ \\
matahari & tiap hari & 1 & $5,3 \%$ \\
& Kadang kadang membuka jendela & 2 & $10,5 \%$ \\
\hline
\end{tabular}

\section{PEMBAHASAN}

Berdasarkan karakteristik yang telah diteliti, mayoritas penderita TB berada pada usia produktif. Hasil ini sesuai dengan pendataan oleh Kementrian Kesehatan tahun 2010 bahwa usia produktif (15-50 tahun) merupakan $75 \%$ dari seluruh penderita $\mathrm{TB}$ paru di Indonesia. ${ }^{11}$

Mobilitas tinggi pada usia produktif dapat meningkatkan resiko terpapar oleh Mycobacterium tuberculosis. Kelompok dengan mobilitas rendah memperkecil kemungkinan untuk terpapar kuman. Reaktivasi kuman yang dormant lebih sering terjadi pada usia produktif walaupun sistem imun pada usia produktif cenderung lebih baik dibandingkan kelompok pada usia yang lebih tua. Hasil penelitian berdasarkan jenis kelamin didapatkan perolehan perempuan sebesar 52,6\% dan laki-laki 47,6\%. Hal ini tidak sesuai dengan data pada penelitian sebelumnya bahwa lebih banyak laki-laki menderita TB dibandingkan perempuan. ${ }^{7,11-13}$

Beberapa penyebab masalah kesehatan secara tidak langsung dapat terlihat dari beberapa faktor antara lain pekerjaan, tingkat pendidikan, dan penghasilan. Pada Tabel 1, 42,1\% responden merupakan lulusan SMA, dan 31,6\% dari responden sebagai pensiunan PNS dan buruh, serta 47,4\% memiliki penghasilan kurang dari Rp 1.050.000. Hasil pada penelitian ini mendukung pernyataan pada studi-studi terdahulu yang menggambarkan penderita TB mayoritas merupakan kelompok ekonomi rendah. Tingkat pendidikan rendah merupakan faktor rendahnya pengetahuan terhadap penyakit TB dan pencegahannya. Pada penelitian ini mayoritas responden merupakan lulusan SMA, walaupun secara teori diungkapkan bahwa pada TB lebih sering terjadi pada kelompok berpendidikan rendah. ${ }^{14-16}$

Mayoritas responden pada penelitian ini memiliki aspek lingkungan yang baik walaupun masih terdapat beberapa karakteristik yang tidak dapat diubah karena menyesuaikan dengan kondisi ekonomi dan sosial pada keluarga tersebut. Ventilasi yang kurang baik meningkatkan kelembapan ruangan, pada kondisi ini pertumbuhan bakteri akan meningkat yang ditambah dengan kurangnya cahaya matahari pada ruangan tersebut. ${ }^{17,18}$ Pengetahuan yang baik mengenai pencegahan penularan penyakit terlihat sudah baik pada sebagian besar sampel. Hal ini kemungkinan didukung oleh tingkat pendidikan yang baik pada mayoritas responden pada penelitian ini. Walapun kejadian TB paru pada penelitian ini terjadi pada kondisi lingkungan, pengetahuan, dan pencegahan yang sudah baik, terjangkitnya responden terhadap TB tidak lepas dari tingkat imunitas dan faktor antigen. ${ }^{15,19}$ Berdasarkan perilaku pencegahan, hasil penelitian ini menunjukkan bahwa sebagian besar responden berobat teratur dan 1 responden memilih berobat alternatif. Mayoritas responden membuang dahak/ meludah di toilet, menjaga sanitasi cahaya dengan membuka jendela kamar tidur setiap hari dengan baik. Hal ini pemperlihatkan bahwa kesadaran penderita TB paru di wilayah kerja Puskesmas Dawan 1 sudah cukup baik dalam mencegah penularan penyakit pada orang di sekitarnya. ${ }^{13-15}$ Kelemahan dari penelitian ini adalah sampel yang kecil sehingga belum dapat memberikan gambaran mengenai pengetahuan dan pola pencegahan secara keseluruhan atau belum dapat mewakili seluruh populasi TB yang ada di Kabupaten Klungkung.

\section{SIMPULAN}

Sebagian besar responden dengan TB paru di wilayah kerja Puskesmas Dawan 1, Kabupaten Klungkung berada pada rentang usia produktif, mayoritas perempuan, status sosial ekonomi rendah, dan tingkat pendidikan yang baik, aspek lingkungan dan pengetahuan pencegahan yang baik.

\section{DAFTAR PUSTAKA}

1. Silva VD., Tigeh S., Wirawan N., Made B. The relationship between education, job, and family income with TB medication dropouts in Timor-Leste. Bali Med J. 2016;5(2):279-282

2. Amin, Zulkifli, Bahar A. Tuberkulosis Paru dalam Buku Ajar Ilmu Penyakit Dalam Edisi Kelima Jilid III. Jakarta: Pusat Penerbitan Ilmu Penyakit Dalam Fakultas Kedokteran Universitas Indonesia. 2009:2230-472 
3. World Health Organization. WHO report on the Global tuberculosis control report. 2016. Diakses pada: 27 Oktober 2017) Tersedia pada: http//www.whqlibdoc.who. int/publications/2011/9789241564380eng.pdf

4. Tolossa D., Medhin G., Legesse M. Community Knowledge, Attitude, And Practices Towards Tuberculosis In Shinile Town, Somali Regional State, Eastern Ethiopia: A Cross-Sectional Study. BMC Public Health. 2014;14:804

5. Perhimpunan Dokter Paru Indonesia. Tuberkulosis: Pedoman, Diagnosis dan Pedoman Penatalaksanaan di Indonesia. Jakarta: Indah Offset Citra Grafika. 2006.

6. World Health Organization. Tuberculosis and gender. 2013. Diakses pada: 13 Maret 2017 Tersedia pada: http:// www.who.int/tb/challenges/gender/page 1/en

7. Dinas Kesehatan Kabupaten Klungkung. Profil Kesehatan Kabupaten Klungkung. Dinas Kesehatan Kabupaten Klungkung. 2014

8. Pranata S. dkk. Riset Kesehatan Dasar Dalam Angka 2013 Provinsi Bali. Jakarta: Badan Penelitian dan Pengembangan Kesehatan Kementerian Kesehatan RI. 2013

9. Rizana N., Tahlil T., Mulyadi. Pengetahuan, Sikap dan Perilaku Keluarga Dalam Pencegahan Penularan Tuberkulosis Paru. Jurnal Ilmu Keperawatan. 2016;4:2

10. Astuti S. Hubungan Tingkat Pengetahuan dan Sikap Masyarakat Terhadap Upaya Pencegahan Penyakit Tuberkulosis di RW 04 Kelurahan Lagoa Jakarta Utara Tahun 2013. UIN Syarif Hidayatullah. 2013

11. Kementerian Kesehatan Republik Indonesia. Hasil Riset Kesehatan Dasar 2010. Kemenkes RI. 2010

12. Zeana C., El-Sadr W. The effect of gender on the epidemiology, clinical presentation, and management of tuberculosis Principles of Gender-specific. Medicine, 2004:938
13. Barker RD. Clinical tuberculosis. Medicine. 2011; 40(6): 340-345

14. Ridwan M. Hubungan Tingkat Pengetahuan dan Sikap Dengan Perilaku pencegahan Penularan Tuberkulosis (Tb) di Wilayah Kerja Puskesmas Ngemplak Kabupaten Boyolali. Universitas Muhamadiyah. 2014

15. Trasia R. F., Aryani P. Gambaran Aspek Lingkungan dan Perilaku Pencegahan Penularan Tuberkulosis Paru di Wilayah Kerja Puskesmas Bebandem, Kabupaten Karangasem. Universitas Udayana. 2012

16. Wahyuni. Determinan Perilaku Masyarakat Dalam Pencegahan, Penularan Penyakit Tbc di Wilayah Kerja Puskesmas Bendosari. GASTER. 2008;4(1):178-183

17. Niko. Tesis: Hubungan Perilaku dengan Kondisi Sanitasi Rumah dengan Kejadian TB Paru di Kota Solok Tahun 2011. Fakultas Kedokteran Universitas Andalas Padang. 2011

18. Chandra Wibowo, Maria CH Winarti, dkk. Kasus Kontak Tuberkulosis Paru di Klinik Paru Rumah Sakit Umum Pusat Manado. Majalah Kedokteran Indonesia. 2004

19. Tobing, Tonny L. Tesis: Pengaruh Perilaku Penderita TB Paru dan Kondisi Rumah Tergadap Pencegahan Potensi Penularan TB Paru Pada Keluarga di Kabupaten Tapanuli Utara. Universitas Sumatera Utara. 2009

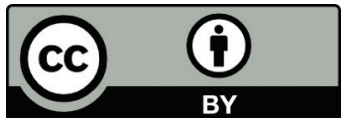

This work is licensed under a Creative Commons Attribution 